\title{
冻土带砂金粒后生长大壳层的发现及其意义*
}

1993 年 5 6 月作者在黑河金矿地质队 协助下考察了我国东北冻土带黑河地区法别 拉河上游五道沟一带的砂金矿点及其岩金 矿, 并分别淘到了一些砂金粒和岩金粒. 经 室内电子探针研究发现, 在五道沟的二支 沟、一支沟, 猪肚子河, 老飞机场河, 南大岗 和嘎拉碃等地淘到了很多砂金粒均具有明显 的后生长大壳层. 而岩金粒均不具有后生长 大壳层, 岩金粒成分接近于砂金粒核部成分 而与砂金粒壳层的成分明显不同. 矿金粒横 截磨光面在电子探针苂光屏放大图象上显示 为较清晰的明亮环边. 不同砂金粒和同一砂 金粒不同部位环边宽度不等,一般宽从 $5 \mu \mathrm{m}$ 以下至 $80 \mu \mathrm{m}$ 不等. 环边与核部接触界限截 然, 属突变性质. 某些颗粒环边的轮廓、变 化形态均较清晰, 但另一些砂金粒环边和核 部的亮度反差小, 不易观察. 砂金粒环边的 外表面一般不很光滑, 有的还长成突出的小 尾巴 (猪肚子河和老飞机场河). 砂金粒较 大裂隙内壁上后生长大边较宽, 且长成枝 状, 牙状、肠状等形态, 参差不齐, 相互穿插 交错; 较小裂隙中则几乎被后生金填泻 (猪 肚子河). 同时还显示出砂金粒裂隙中后生 金生长速率比颗粒环边金生长速率高的趋势 (猪肚子河等).

二支沟砂金粒环边相对较窄 $(5 \mu \mathrm{m}$ 以下 至 $15 \mu \mathrm{m})$, 可能与二支沟近些年淘采砂金过 于频繁、环边生长不起来有关.

电子探针分子 ${ }^{1)}$ 表明, 砂金粒环边中银 的含量与核部相比陡然下降,一般由核部的 $8 \% \sim 14 \%$ 突降至壳层中的 $1 \%$ 或以下; 相
反, 金的含量 (金成色) 则骤然升高,一般由 核部的 $84 \% \sim 94 \%$ 突增至 $97 \% \sim 99 \%$ 左 右. 同时环边中还含有 $\mathrm{Cu}, \mathrm{Ni}, \mathrm{As}, \mathrm{Sb}, \mathrm{Se}, \mathrm{Fe}$, $\mathrm{Zn}, \mathrm{Mn}$ 等杂质, 且含量有波动. 它们可能是 岩金矿体和/或含金岩体中所含的金属硫化 物在风化淋滤作用中与金一起氧化溶解、随 溶液迁移至形成一定水文异常分散晕圈的过 程中一同沉淀的结果, 同时随风化条件的波 动而有所变化.

基于上述特点,作者认为这些砂金粒的 壳层是冻土带岩金风化带特定地段上金以可 溶性络合物形式从风化带溶解迁出, 并随水 溶液性质 ( $\mathrm{pH}, \mathrm{Eh}$ 和电介质等) 的演变逐渐 分异和沉淀的结果. 砂金粒后生环边的发现 为冻土带砂金矿再生和狗头金的形成机理提 供了佐证. 它还预示着黑河地区法别拉河五 道沟一带的砂金矿正处在砂金粒逐渐长大、 品位逐渐升高加富了自然成矿过程中. 同 时,该区某些砂金矿过采区有可能经过若干 年的后生富集作用再重新变成新的砂金矿 区. 因此,应当对过去老的砂金过采区进行 重新评价.

\section{陈福 朱笑青张宝林}

(中国科学院地球化学 (中国科学院长春地理

研究所, 贯阳 550002) 研究所, 长春 130021)

*中国科学院矿床地球化学开放研究实验室资助课题 及所长择优资助项目

1) 中国科学院地球化学研究所电子探针分析室李德忍 分析 